\section{Incidence of Raspberry Bushy Dwarf Virus in Breeding Plots of Red Raspberry}

\author{
M.M. Stahler ${ }^{1}$ \\ U.S. Department of Agriculture-Agricultural Research Service, Horticultural \\ Crops Research Laboratory, 3420 Northwest Orchard Avenue, Corvallis, \\ OR 97330
}

\section{F.J. Lawrence ${ }^{2}$}

U.S. Department of Agriculture-Agricultural Research Service, National Clonal Germplasm Repository, 33447 Southeast Peoria Road, Corvallis, OR 97333

\section{R.R. Martin ${ }^{3}$ \\ Agriculture Canada Research Station, 6660 Marine Drive, Vancouver, B.C. VGT 1X2, Canada}

Additional index words. Rubus idaeus, hybrids, genotype resistance, genotype susceptibility, tobacco streak virus, tomato ringspot virus, enzyme-linked immunosorbent assay

Abstract. More than 300 red raspberry cultivars and selections were screened for raspberry (Rubus idaeus L.) bushy dwarf virus (RBDV), tobacco streak virus (TSV), and tomato ringspot virus (TomRSV) using enzyme-linked immunosorbent assay in three naturally infected breeding program selection plots at Corvallis, Ore. All genotypes tested negative for TSV and TomRSV. The RBDV incidence in primocane-fruiting cultivars and selections was $67 \%$; in floricane-fruiting genotypes, it was $34 \%$. The pattern of RBDV infection in the field showed no discernible trend. The high incidence may have been due to use of infected parents, propagation of infected genotypes, and pollen transmission. 'Willamette', considered to be immune to the common strain of RBDV, along with 14 clones that had been in the field 10 years or longer, tested negative. The high incidence of RBDV in the breeding plots may provide an opportunity to identify resistant parents for breeding programs. An early seedling screening method for RBDV susceptibility is desirable to eliminate highly susceptible genotypes from the program and maintain a lower incidence of RBDV within the breeding plots.

Raspberry bushy dwarf virus (RBDV) is a naturally occurring pollen-borne viral disease that infects susceptible red and black raspberries and blackberry $\mathrm{X}$ raspberry hybrids (Converse, 1991; Murant, 1987). Wild Rubus species are also infected by RBDV (Converse, 1991). Daubeny et al. (1978, 1982) reported that, in the Pacific Northwest, significant yield losses, cane vigor decline, and drupelet abortion occurred due to RBDV infection. The cultivar Willamette, which is considered immune to the common strain (Converse, 1991; Knight and Barbara, 1981), has been gradually replaced in large commercial plantings in the Pacific Northwest with susceptible cultivars such as 'Meeker', 'Chilliwack', and 'Skeena' (Daubeny et al., 1982). The resis-

Received for publication 20 May 1994. Accepted for publication 6 Oct. 1994. The cost of publishing this paper was defrayed in part by the payment of page charges. Under postal regulations, this paper therefore must be hereby marked advertisement solely to indicate this fact.

${ }^{1}$ Research Geneticist. Current address: U.S. Dept. of Agriculture Natural Resources Conservation Service, Plant Materials Center, 3415 NE Granger Ave., Corvallis, OR 97330-9620.

${ }^{2}$ U.S. Dept. of Agriculture Collaborator.

${ }^{3}$ Research Scientist. tance breaking (RB) strain of RBDV has not been reported in North America (H.A. Daubeny, personal communication).
Infected plants and seedlings have been propagated within breeding programs, and exchange of breeding material between programs may have spread the disease despite the use of some RBDV-free stock. Additional spread of the disease within fields is due to the transferal of infected pollen from RBDV-infected plants to noninfected plants. The only effective control of RBDV is through the development and use of resistant cultivars.

The objective of this study was to determine the extent of RBDV, tomato ringspot virus (TomRSV), and tobacco streak virus (TSV) infection within the U.S. Dept. of Agriculture (USDA)-Oregon State Univ. Cooperative Raspberry Breeding Program in Corvallis, Ore., and to use a naturally occurring epidemic to identify possible resistant plant materials to be used in future crosses. While some of the RBDV negative selections may prove to be escapes, additional testing will determine their true status.

All of the fields for clonal evaluation consisted of nonreplicated floricane and primocane advanced selections and important clones planted in groups of three plants (Fig. 1). History of exposure of most of these clones to RBDV is not known, although plants of some clones were from virus-free sources. Two established selection fields were sampled in May 1992, by taking a composite sample of leaf tissue from three canes of each of the three plants. Every plant in a third field was sampled to determine the incidence of the three viruses and to obtain more epidemiological information.

Samples were analyzed using triple-antibody sandwich enzyme-linked immunosorbent assay (ELISA) for TomRSV and TSV and double-antibody sandwich ELISA for RBDV (Converse and Martin, 1991). Of the more than 300 genotypes screened, none were positive for TomRSV or TSV. However, there was a high incidence of RBDV in all fields regardless of the year the field was established. A
LEWIS BROWN FARM

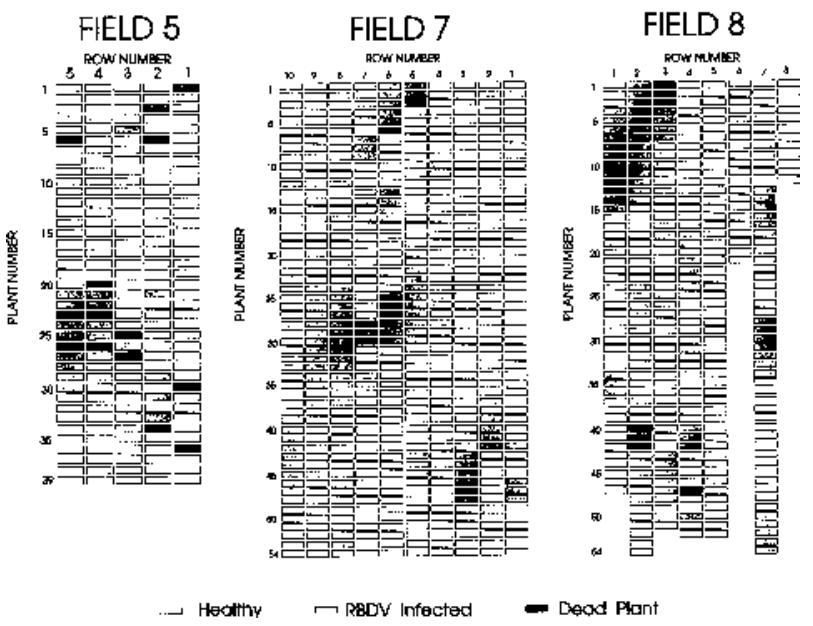

Fig. 1. The incidence of raspberry bushy dwarf virus disease in three breeding program selection fields. In Lewis Brown farm (LB) 5, established in 1991, rows 4 and 5 and plants 38-39 in row 3 are primocanebearing. LB 7 was planted from 1985 , rows $1-4 ; 1987$, rows $5-7 ; 1988$, rows 8-9; to 1989 , row 10 . Rows 1 and 2 are primocane-bearing. In LB 8, rows 1-4 were planted in 1989; rows 5-8 were planted in 1990. Rows 2, 3, and 7 are primocane-fruiting. The remaining rows in all three fields are floricane-fruiting. 
Table 1. Raspberry clones tested virus-free for raspberry bushy dwarf virus after 10 years or longer of field exposure at Corvallis, Ore., 1992.

\begin{tabular}{|c|c|c|}
\hline ORUS $^{2}$ clone & Parentage & $\begin{array}{c}\text { Exposure } \\
\text { (years) }\end{array}$ \\
\hline$\overline{1582}$ & Puyallup x ORUS 1088 (ORUS 1028 x Willamette) & 25 \\
\hline 1584 & Puyallup x ORUS 1088 & 25 \\
\hline 1780B & Meeker X Matsqui & 20 \\
\hline 1838 & Fallred x ORUS 1347 (Newburgh x ORUS 902) & 19 \\
\hline $1994(4 X)$ & Malling Jewel x Ark 62-59-1 & 17 \\
\hline $610-3$ & $\begin{array}{l}\text { ORUS } 1747 \text { (SHRI } 6145 / 42 \times \text { Willamette) } \times \text { ORUS } \\
1790 \text { (ORUS } 1441 \text { x ORUS 1416) }\end{array}$ & 14 \\
\hline $613 R-2$ & $\begin{array}{l}\text { ORUS } 1574 \text { (Creston } \times \text { ORUS 1094) x ORUS } 1448 \\
\text { (Malling Promise } x \text { ORUS 1110) }\end{array}$ & 14 \\
\hline $613 \mathrm{R}-8$ & ORUS 1574 x ORUS 1448 & 14 \\
\hline $661-1$ & Amity $x$ Scepter & 14 \\
\hline $688-10$ & ORUS 1815 (ORUS $1412 \times$ Canby) x Skeena & 12 \\
\hline $706-2$ & ORUS 1780 (Meeker X Matsqui) X Meeker & 11 \\
\hline $717-5$ & $\begin{array}{l}\text { ORUS } 1796 \text { (Willamette x Sentinel) x ORUS } 1679 \\
\text { (Malling Promise x ORUS 1153) }\end{array}$ & 11 \\
\hline $719-3$ & $\begin{array}{l}\text { ORUS } 1790 \text { (ORUS } 1441 \times \text { ORUS 1416) x ORUS } 1793 \\
\text { (Canby } \times \text { Willamette) }\end{array}$ & 11 \\
\hline $767-2$ & $\begin{array}{l}\text { ORUS } 1789 \text { (ORUS } 1441 \times \text { ORUS 1416) x ORUS } 1871 \\
\text { (Matsqui x SHRI 6626/41) }\end{array}$ & 10 \\
\hline
\end{tabular}

${ }^{2}$ Oregon-U.S. Dept. of Agriculture.

higher percentage of the primocane-fruiting selections $(67 \%)$ was infected with RBDV than of the floricane-fruiting selections (34\%).

About 300 clones from the breeding program, including several cultivars, had been in the field 10 years or more. Fourteen clones and 'Willamette' tested virus-free (Table 1). Five clones in test fields for 17 years or longer may be highly resistant or possibly immune. These clones could be useful breeding stock for resistance to RBDV. Although the disease pressure in the fields has been very high over the years, the true resistance status of these clones needs to be determined through inoculation under controlled conditions. The high incidence of RBDV within the USDA selection plots in Corvallis could have been due to use of infected parents, propagation of infected genotypes, and transmission within the planting.

Eliminating highly susceptible seedlings at an early stage, before selection and propagation, would be useful. A suggested method to identify highly susceptible genotypes may be to maintain a low incidence of RBDV within breeding plots and test for RBDV in seedlings (H.A. Daubeny, personal communication). Jennings and Jones (1989) stated that naturally occurring field infections could prove to be more effective than graft inoculation of many plants for RBDV resistance screening.

An analysis of the inheritance of resistance or susceptibility to RBDV was not possible in this study. Pedigree analysis was confounded by several factors: 1) the RBDV infection status of parents used in actual crosses was unknown at the time of crossing; 2) many selections used as intermediate parents in the breeding program have been discarded and their resistance or susceptibility is unknown; 3 ) the clones in the field were advanced selections and the nonselected progeny were never tested.

\section{Literature Cited}

Converse, R.H. 1991. Pollen-transmitted diseases. Raspberry bushy dwarf virus. In: M.A. Ellis, R.H. Converse, R.N. Williams, and B. Williamson (eds.). Compendium of raspberry and blackberry diseases and insects. APS Press, St. Paul, Minn.

Converse, R.H. and R.R. Martin. 1991. ELISA for plant viruses. In: R. Hampton, E. Ball, and S. DeBoer (eds.). Serological methods for detection and identification of viral and bacterial plant pathogens. APS Press, St. Paul, Minn.

Daubeny, H.A., J.A. Freeman, and R. Stace-Smith. 1982. Effect of raspberry bushy dwarf virus on yield and cane growth in susceptible red raspberry cultivars. HortScience 17:645-657.

Daubeny, H.A., R. Stace-Smith, and J.A. Freeman. 1978. The occurrence and some effects of raspberry bushy dwarf virus in red raspberry. J. Amer. Soc. Hort. Sci. 107:593-597.

Jennings, D.L. and A.T. Jones. 1989. Further studies on the occurrence and inheritance of resistance in red raspberry bushy dwarf virus. Ann. Appl. Biol. 114:317-323.

Knight, V.H. and D.J. Barbara. 1981. Susceptibility of red raspberry varieties to raspberry bushy dwarf virus and its genetic control. Euphytica 30:803-811.

Murant, A.F. 1987. Pollen borne diseases. In: R.H. Converse (ed.). Virus diseases of small fruits. U.S. Dept. Agr., Agr. Hdbk. 631. 